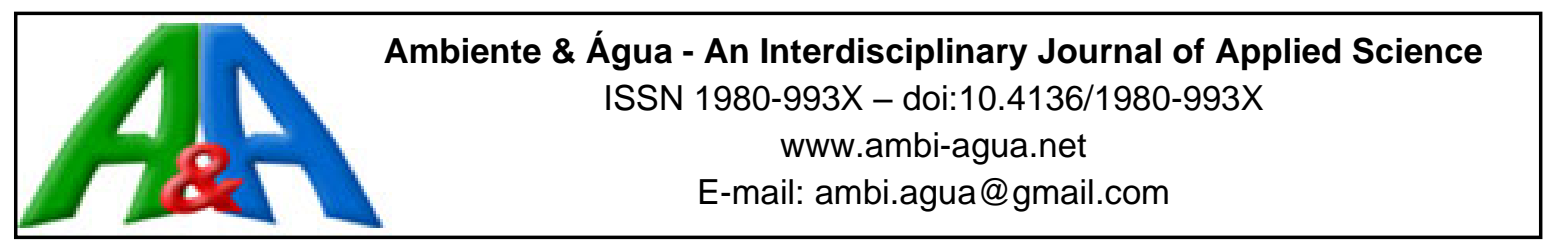

\title{
Performance evaluation and coefficients of reliability for waste stabilization ponds in northeast Brazil
}

\author{
ARTICLES doi:10.4136/ambi-agua.2571 \\ Received: 04 May 2020; Accepted: 24 Nov. 2020 \\ Matheus Sales Alves ${ }^{1 * i D}$; Fernando José Araújo da Silva1 ${ }^{1 D}$; \\ André Luís Calado Araújo ${ }^{2}$; Erlon Lopes Pereira ${ }^{1}$ \\ ${ }^{\mathbf{1} D e p a r t a m e n t o ~ d e ~ E n g e n h a r i a ~ H i d r a ́ u l i c a ~ e ~ A m b i e n t a l ~(D H E E) . ~ U n i v e r s i d a d e ~ F e d e r a l ~ d o ~ C e a r a ́ ~(U F C), ~}$ \\ Rua do Contorno, s/n, Bloco 713, CEP: 60451-970, Fortaleza, CE, Brazil. \\ E-mail: fjas@deha.ufc.br, erlonlopes@gmail.com \\ ${ }^{2}$ Diretoria de Recursos Naturais. Instituto Federal de Educação, Ciência e Tecnologia do Rio Grande do Norte \\ (IFRN), Avenida Senador Salgado Filho, n 1559, CEP: 59015-000, Natal, RN, Brazil. \\ E-mail: andre.calado@ifrn.edu.br \\ *Corresponding author. E-mail: matheus.sales.ufv@gmail.com
}

\begin{abstract}
This paper assesses the reliability of Waste Stabilization Ponds (WSP) and proposes an alternative approach to WSP design based on the calculation of coefficient of reliability (COR) from an acceptable measure of violation of discharge standards. For that, data were collected from 10 full-scale systems operating in Northeast Brazil. All systems receive predominantly domestic effluent and are composed of one facultative pond and two serial maturation ponds. Different levels of restriction for effluent discharge were considered regarding the parameters: BOD, COD, total suspended solids, ammonia and thermotolerant coliforms. The Log-normal Probability Distribution Function (PDF) was able to represent the behavior of the concentration data in the effluent and, therefore, allowed the COR calculation. The COR was obtained from the coefficient of variation $(\mathrm{CV})$ of the concentrations and the standardized normal variable associated with a 95\% probability of non-exceedance. The observed dispersion of the results proved to be detrimental to the adoption of a single COR value for the evaluated parameters. In addition, the comparison between observed and design/operational concentration for optimal performance showed that the $95 \%$ reliability scenario represents a less achievable target for WSP systems.
\end{abstract}

Keywords: effluent quality, reliability, waste stabilization ponds.

\section{Avaliação do desempenho e coeficientes de confiabilidade de lagoas de estabilização no nordeste do Brasil}

\section{RESUMO}

Este trabalho tem como objetivo avaliar a confiabilidade de Lagoas de Estabilização e propor uma abordagem alternativa à concepção destes sistemas baseada no cálculo do coeficiente de confiabilidade (CDC) com base numa medida aceitável de violação das normas de lançamento. Para tal, foram coletados dados de 10 sistemas em escala real que operam no Nordeste do Brasil. Todos os sistemas recebem efluentes predominantemente domésticos e são compostos por uma lagoa facultativa e duas lagoas de maturação em série. Foram considerados 
diferentes níveis de restrição para o lançamento de efluentes no que diz respeito aos parâmetros: DBO, DQO, Sólidos Suspensos Totais, Amônia total e Coliformes Termotolerantes. A Função de Distribuição de Probabilidade Log-normal (FDP) mostrou-se apta para representar o comportamento dos dados de concentração no efluente e, portanto, permitiu o cálculo do CDC. O CDC foi obtido a partir do coeficiente de variação $(\mathrm{CV})$ das concentrações e da variável normal padronizada associada a uma probabilidade de $95 \%$ de não excedência. A dispersão observada dos resultados de CDC revelou-se prejudicial à adopção de um único valor para os parâmetros avaliados. Além disso, a comparação entre a concentração observada e a concentração de projeto/operacional para um desempenho ótimo mostrou que o cenário de $95 \%$ de confiabilidade representa um objetivo pouco factível para os sistemas de lagoas de estabilização.

Palavras-chave: confiabilidade, lagoas de estabilização, qualidade dos efluentes.

\section{INTRODUCTION}

Benedetti et al. (2010) defined the reliability of a wastewater treatment plant (WWTP) as the probability of the effluent concentrations to comply with specified discharge standards or treatment objectives during a given period of time. Equation 1:

$$
\text { Reliability }=1-p(\text { effluent concentration }>\text { effluent requirement })
$$

The probability (p) of the standard or a target being exceeded in the effluent depends on the distribution function describing the quality parameters concentrations. In this sense, the right-skewed probabilistic distributions are particularly common when the analyzed mean data are low, present large variance, and cannot be negative (Limpert et al., 2001), such as WWTP effluents.

Thus, Niku et al. (1979) based themselves on the lognormal distribution in order to develop the coefficient of reliability (COR), an index that relates the mean concentration of a parameter to the quality standards to be complied with a required reliability level. The COR was developed based on TSS and BOD data from activated sludge systems, wastewater treatment processes with high degree of mechanization and operational flexibility. This method is recommended for use by the USEPA (Niku and Schroeder, 1981) and recognized in the technical literature (Tchobanoglous et al., 2003; Oliveira and Von Sperling, 2008; OwusuAnsah et al., 2015; Andraka, 2019).

Later, comparative reliability studies by Oliveira and Von Sperling (2008) and Alderson et al. (2015) provided the COR of several wastewater treatment processes in Brazil. Still, few discussions were held on the practical applicability of COR results in natural systems with passive operation, such as Waste Stabilization Ponds (WSP), or consider different levels of restriction for discharge standards into water bodies. According to Weirich et al. (2011), the discharge standards are based on scientific criteria of water quality and the risk of significant adverse effects on the receiving water bodies. However, the imposition of regulatory limits that do not consider the regional socio-economic, institutional and climatic conditions may prevent the adoption of certain treatment technologies.

Based on the above, this study evaluated the performance and the coefficients of reliability (COR) for full scale WSP systems operating in Northeast Brazil. It also analyzes compliance with different criteria for effluent discharge and proposes an alternative approach for the design of WSPs based on the COR. We hope that the considerations of this study may contribute both in the design of new systems and in the definition of reasonable discharge standards by regulatory agencies. 


\section{MATERIALS AND METHODS}

\subsection{Waste Stabilization Pond systems and data collection}

Data from 10 WSP systems in the state of Rio Grande do Norte, Northeast Brazil, were used to develop this study (Table 1). The spatial distribution of the systems integrates different climatic conditions within the state, from tropical rainfall to semi-arid (Köppen classification), with average temperatures above $20^{\circ} \mathrm{C}$ and average annual precipitation between 400 and 1200 mm.

Table 1. Location and general characterization of the WSP systems studied.

\begin{tabular}{|c|c|c|c|c|c|}
\hline WSP & Location & Designation & Start of operation & $\begin{array}{l}\text { Flow rate } \\
\left(\mathrm{m}^{3} \mathrm{~d}^{-1}\right)\end{array}$ & $\begin{array}{l}\text { Hydraulic retention } \\
\text { time }(\mathrm{d})\end{array}$ \\
\hline Caiçara & $\begin{array}{c}5^{\circ} 45^{\prime}, 27^{\prime \prime} \mathrm{S} \\
35^{\circ} 59^{\prime} 44^{\prime \prime} \mathrm{W}\end{array}$ & $\mathrm{S} 1$ & 2002 & 108 & 29.7 \\
\hline Ilha de Santana & $\begin{array}{c}5^{\circ} 07^{\prime} 17^{\prime \prime} \mathrm{S} \\
36^{\circ} 38^{\prime} 09^{\prime \prime} \mathrm{W}\end{array}$ & $\mathrm{S} 2$ & 1996 & 3940 & 17.1 \\
\hline Passagem de Pedras & $\begin{array}{c}5^{\circ} 11^{\prime} 53^{\prime \prime} \mathrm{S} \\
37^{\circ} 18^{\prime} 44^{\prime \prime} \mathrm{W}\end{array}$ & S3 & 2009 & 492 & 118.0 \\
\hline Cidade & $\begin{array}{c}6^{\circ} 26^{\prime}, 22^{\prime \prime} \mathrm{S} \\
35^{\circ} 13,18^{\prime \prime} \mathrm{W}\end{array}$ & $\mathrm{S} 4$ & 2002 & 253 & 13.7 \\
\hline Pipa & $\begin{array}{c}6^{\circ} 14^{\prime} 17^{\prime \prime} \mathrm{S} \\
35^{\circ} 04^{\prime} 02^{\prime \prime} \mathrm{W}\end{array}$ & S5 & 2003 & 646 & 18.4 \\
\hline Ponta Negra & $\begin{array}{c}5^{\circ} 53^{\prime} 31^{\prime \prime} \mathrm{S} \\
35^{\circ} 11^{\prime} 04^{\prime \prime} \mathrm{W}\end{array}$ & S6 & 2001 & 7615 & 24.9 \\
\hline Sítio Santana & $\begin{array}{c}6^{\circ} 45^{\prime} 58^{\prime \prime} \mathrm{S} \\
36^{\circ} 43^{\prime} 52^{\prime \prime} \mathrm{W}\end{array}$ & S7 & 2002 & 170 & 29.4 \\
\hline Santo Antônio & $\begin{array}{c}6^{\circ} 18^{\prime} 45^{\prime \prime} \mathrm{S} \\
35^{\circ} 28^{\prime} 24^{\prime \prime} \mathrm{W}\end{array}$ & S8 & 2004 & 300 & 78.0 \\
\hline Coqueiros & $\begin{array}{c}5^{\circ} 47^{\prime} 39^{\prime \prime} \mathrm{S} \\
35^{\circ} 18,34 ” \mathrm{~W}\end{array}$ & S9 & $*$ & 260 & 43.5 \\
\hline Touros & $\begin{array}{c}5^{\circ} 12^{\prime} 15^{\prime \prime} \mathrm{S} \\
35^{\circ} 27^{\prime} 30^{\prime \prime} \mathrm{W}\end{array}$ & S10 & 2000 & 810 & 33.6 \\
\hline
\end{tabular}

* Information not found.

The selection of the wastewater treatment plants considered the proper operation and the existence of preliminary treatment units (bar screen, grit chambers and Parshall flume). All receive mainly domestic effluent and are composed of a facultative pond (FP) followed by two series maturation ponds (MP1 and MP2) (Table 2).

Table 2. Morphometric characteristics of the ponds.

\begin{tabular}{cccccccccc}
\hline & \multicolumn{3}{c}{ Depth $(\mathrm{m})$} & \multicolumn{3}{c}{ Area $\left(\mathrm{m}^{2}\right)$} & \multicolumn{3}{c}{ Length $(\mathrm{m}) /$ Width $(\mathrm{m})$} \\
\hline & FP & MP1 & MP2 & FP & MP1 & MP2 & FP & MP1 & MP2 \\
\hline S1 & 1.50 & 1.40 & 1.40 & 1119 & 546 & 546 & 2.50 & 1.20 & 1.20 \\
S2 & 2.00 & 1.50 & 1.50 & 22950 & 7200 & 7200 & 2.80 & 2.00 & 2.00 \\
S3 & 2.00 & 1.50 & 1.50 & 17775 & 7505 & 7505 & 2.80 & 1.20 & 1.20 \\
S4 & 2.00 & 1.50 & 1.50 & 1352 & 260 & 260 & 2.00 & 2.60 & 2.60 \\
S5 & 2.00 & 1.50 & 1.50 & 4600 & 896 & 896 & 2.90 & 3.50 & 3.50 \\
S6 & 2.00 & 1.50 & 1.50 & 52510 & 28028 & 28548 & 3.80 & 1.40 & 1.90 \\
S7 & 1.30 & 1.20 & 1.20 & 2698 & 703 & 551 & 1.90 & 2.10 & 2.60 \\
S8 & 2.00 & 1.50 & 1.50 & 8418 & 2287 & 2090 & 2.30 & 1.60 & 2.80 \\
S9 & 2.00 & 1.90 & 1.90 & 3024 & 1386 & 1386 & 1.70 & 0.80 & 0.80 \\
S10 & 1.10 & 1.00 & 1.00 & 12876 & 6552 & 6552 & 2.40 & 0.90 & 0.90 \\
\hline
\end{tabular}

Rev. Ambient. Água vol. 16 n. 1, e2571 - Taubaté 2021 
Each system was evaluated with a minimum monthly frequency for a period of one year, on different days of the week, totaling 157 collections. The methodology described in APHA et al. (2012) was used for the characterization of affluents and effluents of each pond with respect to the following parameters: Biochemical Oxygen Demand of filtered (BODf) and unfiltered samples (BOD), Chemical Oxygen Demand of filtered (CODf) and unfiltered samples (COD), total suspended solids (TSS), total ammonia (TAM) and thermotolerant coliforms (TTC). The choice of these parameters is justified by their environmental relevance and by the fact that they are usually contemplated in the legislation that deals with effluent discharge standards.

\subsection{Determination and exclusion of outliers}

Knowing that extreme or unusual values can affect the analysis of the data behaviour, it was decided to identify and exclude outliers. For this, an empirical rule based on the interquartile range of the data set (Von Sperling et al., 2020) was used, according to Equations 2 and 3. All values below the lower limit or above the upper limit were considered outliers and therefore excluded from the analyzed data set.

$$
\begin{aligned}
& L_{\text {up }}=Q_{3}+1,5 \times\left(Q_{3}-Q_{1}\right) \\
& L_{\text {low }}=Q_{1}-1,5 \times\left(Q_{3}-Q_{1}\right)
\end{aligned}
$$

Which: $Q_{3}=$ Third quartile; $Q_{1}=$ First quartile.

\subsection{Compliance with final effluent quality standards}

The concentration data in the final effluent of the $10 \mathrm{WSP}$ was compared with the discharge limits of CONAMA Resolution $n^{\circ} 430 / 2011$ (Conama, 2011) and the levels of restriction for discharge standards proposed by Morais et al. (2019) based on the analysis of Brazilian state legislation (Table 3).

Table 3. Restriction levels for effluent discharge standards adapted from Morais et al. (2019).

\begin{tabular}{ccc}
\hline Parameter & Very Restrictive & Less Restrictive \\
\hline COD $\left(\mathrm{mg} \mathrm{L}^{-1}\right)$ & $<120$ & $>200$ \\
BOD $\left(\mathrm{mg} \mathrm{L}^{-1}\right)$ & $<60$ & $>90$ \\
TSS $\left(\mathrm{mg} \mathrm{L}^{-1}\right)$ & $<100$ & $>150$ \\
TAM $\left(\mathrm{mg} \mathrm{L}^{-1}\right)$ & $<5$ & $>20$ \\
TTC $\left(\mathrm{CFU} 100 \mathrm{~mL}^{-1}\right)$ & $<10^{4}$ & $>10^{5}$ \\
\hline
\end{tabular}

\subsection{Adherence test and coefficient of reliability (COR) calculation}

The methodology developed by Niku et al. (1979) is based on the log-normality of data. The Kolmogorov-Smirnov (K-S) test was applied to evaluate the adherence of effluent concentrations to the log-normal probability distribution $(\alpha=0.05)$. Although several statistical inference techniques are known to analyze data adherence (Kolmogorov-Smirnov, Chi-square, Anderson-Darling and Lilliefors), the K-S test was selected because of its simplicity and because it is the most recommended for small samples $(\mathrm{n} \leq 30)$.

The coefficients of reliability (COR) were calculated for the quality parameters from the coefficients of variation (CV) of the effluent concentrations and the standardized normal variable associated with a probability of non-exceedance of $95 \%$, according to the sequence presented in Figure 1. 


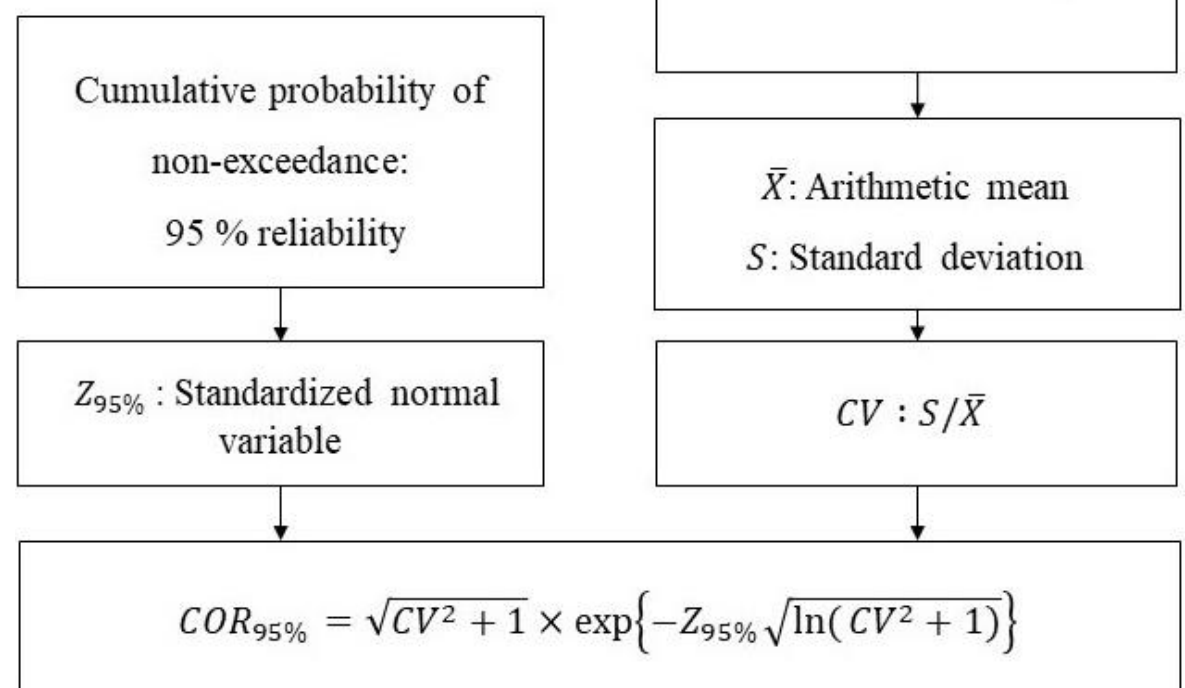

Figure 1. Calculation procedure for coefficients of reliability (COR).

Once the CDC of each parameter was obtained, the design/operational values (Mx) that result in compliance with the discharge standards (Xs) during $95 \%$ of the time, were calculated by Equation 4 for all ponds in the series. Thus, the closer the observed mean concentrations are to the calculated COR concentrations, the closer the WSP systems are to the desired reliability level.

$$
M x=(C D C) \times X s
$$

Which:

Mx: mean parameter concentration.

Xs: Quality target or standard set by some environmental legislation.

COR: coefficients of reliability.

\section{RESULTS AND DISCUSSION}

\subsection{Compliance with quality standards in the final effluent}

Figures 2 and 3 present the Box-plot graphs of concentrations in the final effluents and the percentages of compliance with the different quality standards established for BOD and COD, considering filtered and unfiltered samples.

Despite the difference between flow rates, hydraulic retention times and geometric relations of the units, the systems showed similar behavior in terms of BOD and COD removal efficiency. The average removal efficiency was between $79 \%$ and $89 \%$ for BOD and between $78 \%$ and $87 \%$ for COD. Therefore, all systems complied with the minimum $60 \%$ removal established by the Brazilian federal standard (Conama, 2011) based on filtered BOD samples.

Nevertheless, low percentages of compliance with BOD and COD limits were observed when unfiltered samples are considered (Figure 2.b and 2.a). This is due to the unfiltered material contributing up to $56 \%$ of BOD and $67 \%$ of COD. This high content of particulate organic matter in the effluent can be attributed to the algal biomass present in the pond effluent, which may or may not cause an oxygen demand in receiving waters. 

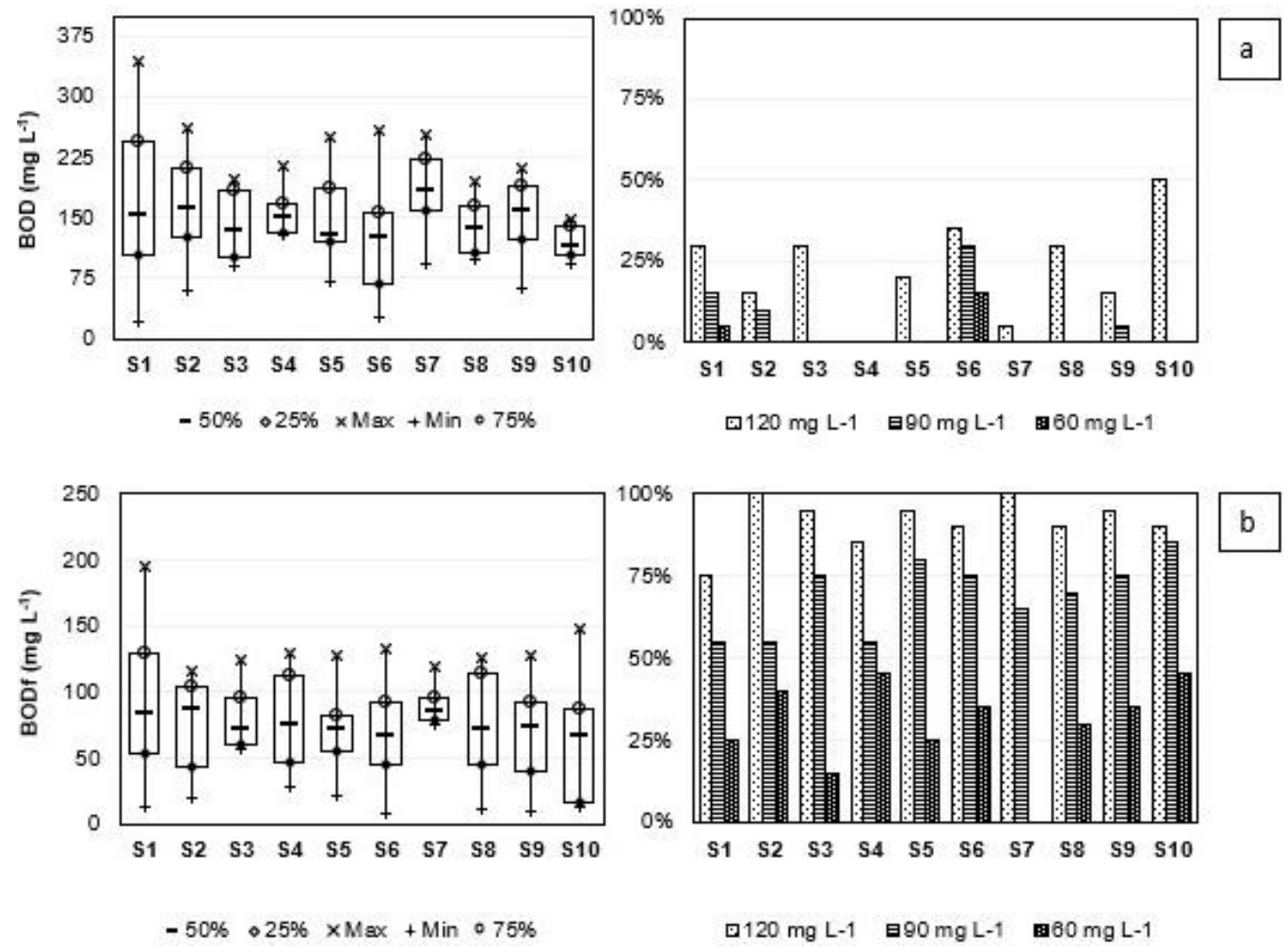

Figure 2. Box-plot graph with the final concentrations and percentages of samples that complied with the quality standards for BOD (a) and BODf (b).
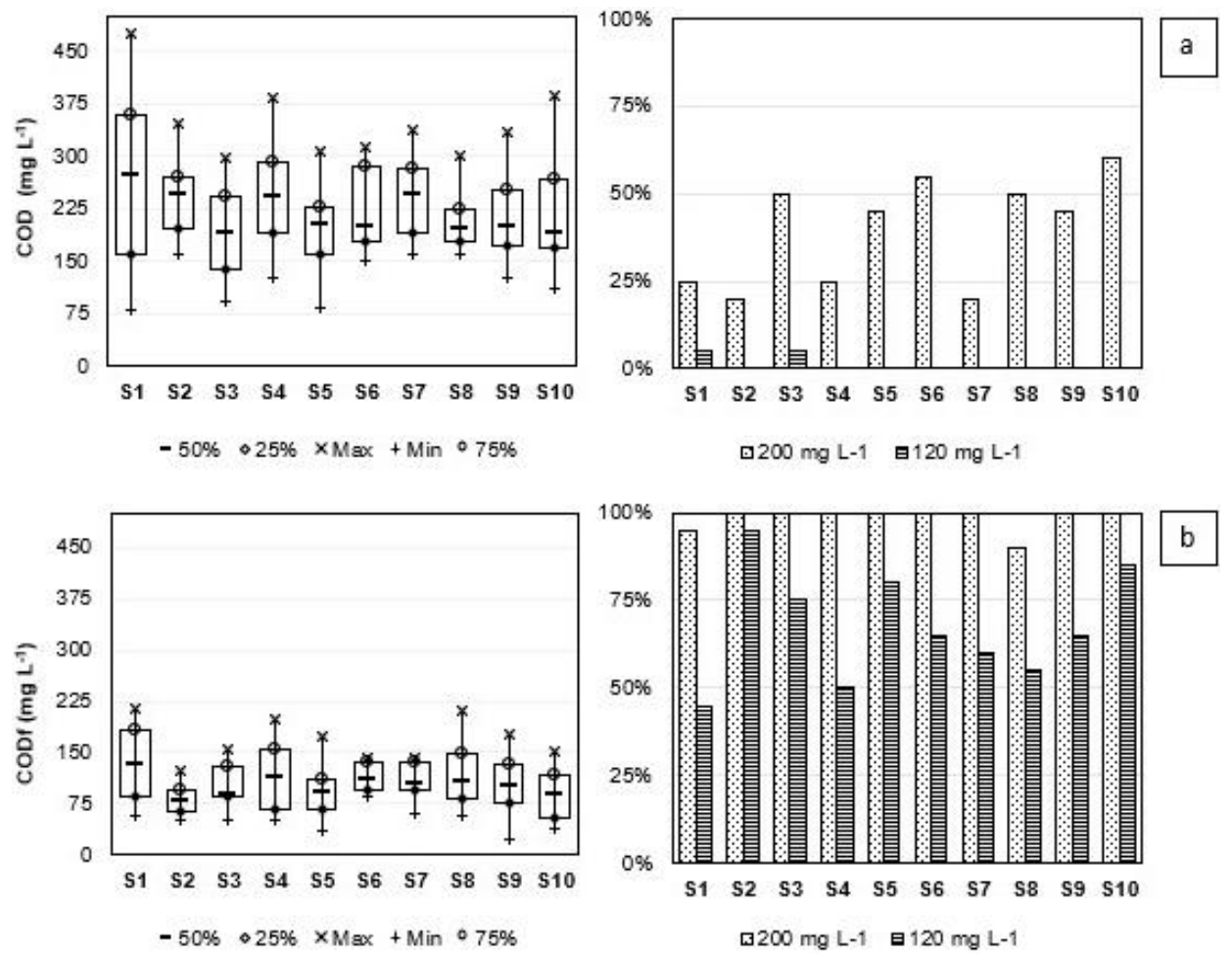

Figure 3. Box-plot graph with the final concentrations and percentages of samples that complied with the quality standards for COD (a) and CODf (b).

Figure 4 presents the box-plot graph of concentrations in the final effluents and the percentages of compliance with the two restriction levels for discharge standards for total suspended solids - TSS, thermotolerant coliforms - TTC, total ammonia - TAM. 

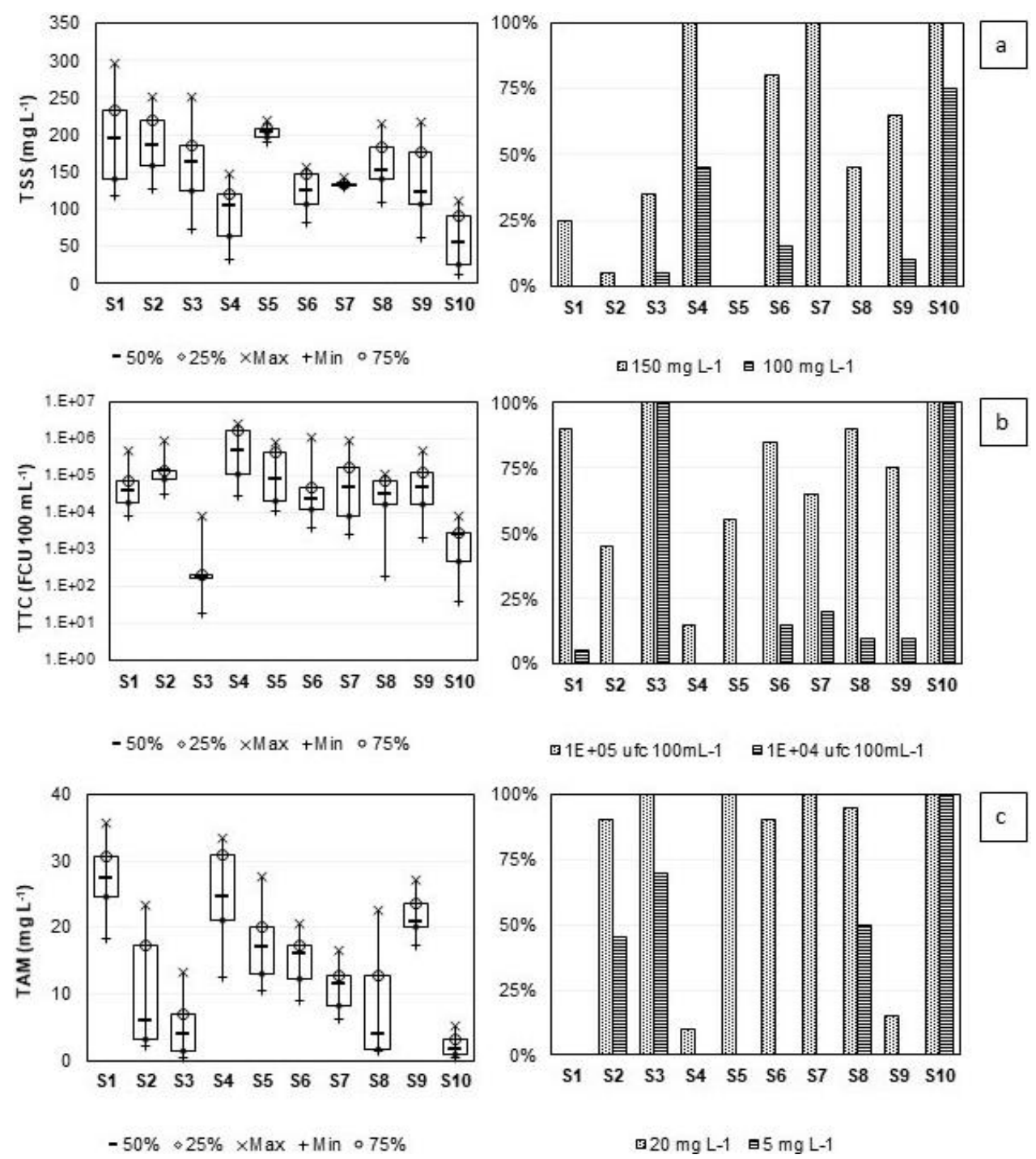

Figure 4. Box-plot graph with the final concentrations and percentages of samples that complied with the quality standards for TSS (a), TTC (b) and TAM (c).

For total suspended solids (4.a), the concentration in the final effluent range from $59 \mathrm{mg}$ $\mathrm{L}^{-1}$ to $204 \mathrm{mg} \mathrm{L}^{-1}$, with average removal efficiencies below $70 \%$. In the final effluent of S3 and S5 increases of $98 \%$ and $62 \%$ were observed in relation to the raw effluent sewage. As BOD and suspended solids are closely related in the treatment (Weirich et al., 2011), it is possible that these results are also associated with algae growth in the ponds. Overall, the WSP systems proved to be unable to comply with the $100 \mathrm{mg} \mathrm{L}^{-1}$ limit in the final effluent (Figure 4.a). Mara (2003) argues that many rivers in developing countries have a "naturally" high suspended solids concentration and therefore it would not make sense to establish stricter standards than the already existing concentration in the receiving water.

The systems presented thermotolerant coliform removal efficiencies between two (99\%) to four logarithmic units (99.99\%). The geometric mean of coliforms ranged from $9.3 \times 10^{2} \mathrm{CFU}$ $100 \mathrm{~mL}^{-1}$ to $8.7 \times 10^{5} \mathrm{CFU} 100 \mathrm{~mL}^{-1}$. Figure $4 . \mathrm{b}$ shows low percentages of compliance with the target of $1.0 \times 10^{4} \mathrm{CFU} 100 \mathrm{~mL}^{-1}$. There is a semi-quantitative relationship between the density of the indicator organism and the presence of pathogens in the effluent. Although the federal standard (Conama, 2011) does not specify a limit for coliforms to be discharged into watercourses, the use of untreated water by rural and peri-urban communities (Mara, 2003) added to the low water availability in the semi-arid region of northeastern Brazil overcomes the need to achieve low counts in the final effluent. 
For ammonia, removal efficiencies ranged from $29 \%$ to $94 \%$. For similar systems in operation in the Northeast, Silva et al. (2011) reported ammonia removals between 30 and $80 \%$. The final effluents presented average ammonia concentrations between $2.0 \mathrm{mg} \mathrm{L}^{-1}$ and $27.2 \mathrm{mg}$ $\mathrm{L}^{-1}$. Only S2, S3, S8 and S10 had ammonia concentrations in the final effluent below the more restrictive quality standard of $5 \mathrm{mg} \mathrm{L}^{-1}$ (Figure 4.c). Considering a scenario of reuse of these effluents in agriculture, the availability of nutrients can be considered as a favorable aspect for crop growth.

The observed variations in performance and final effluent quality illustrate the need for WSP systems to be designed to produce an average effluent concentration well below discharge standards. Thus, the coefficient of reliability (COR) proposed by Niku et al. (1979) presents itself as an attractive methodological alternative by relating the mean effluent concentration values to the standard to be complied with based on an acceptable measure of risk or violation.

\subsection{Coefficient of reliability (COR)}

Figure 5 presents the box-plot graphs of coefficients of Variation (CV) and COR per parameter over the pond series.

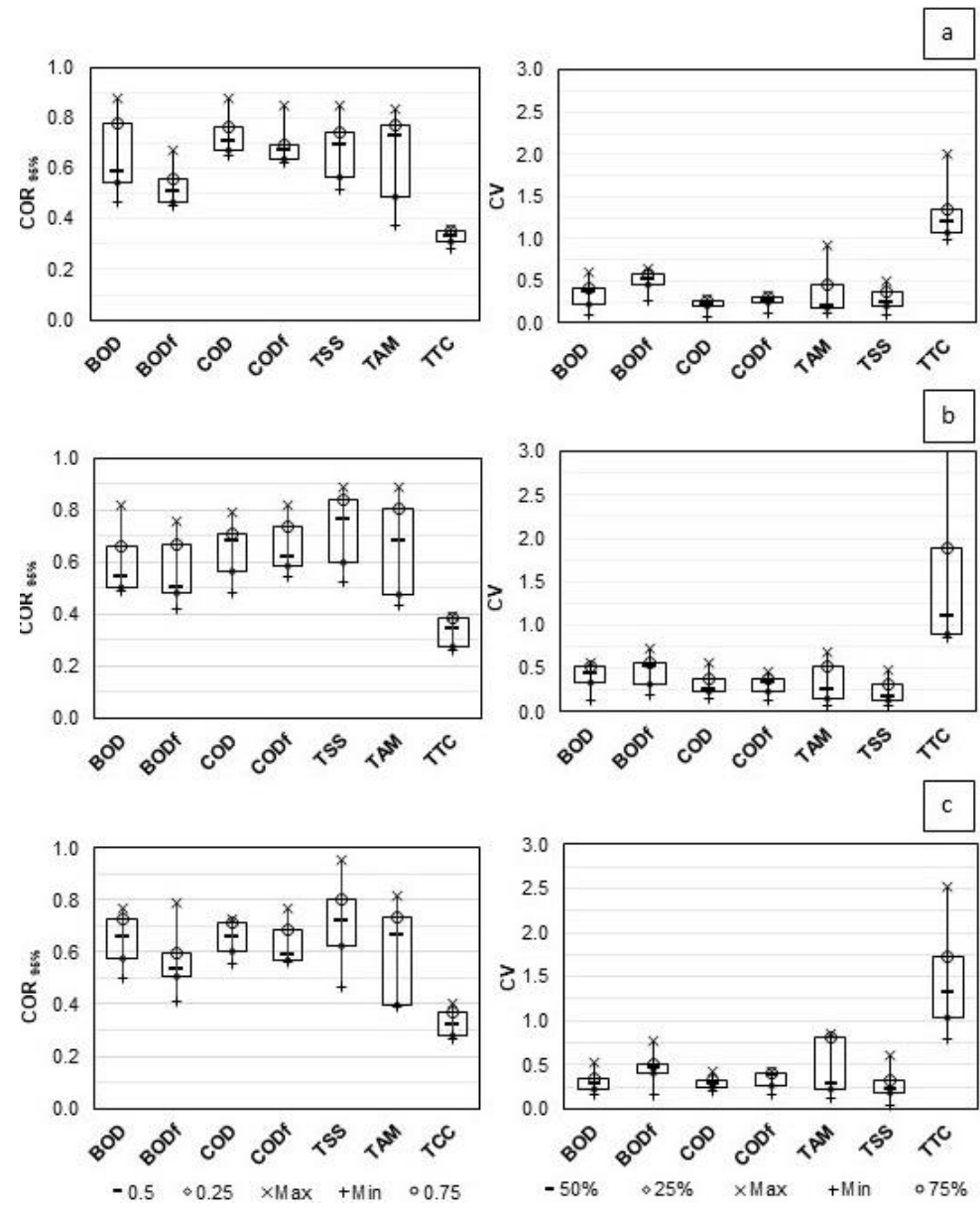

Figure 5. Box-plot of the coefficient of variation (CV) expressed non-dimensionally and the coefficient of reliability (COR) per parameter in the effluent of FP (a), MP1 (b), MP2 (c), calculated for a $95 \%$ reliability level.

The K-S adherence test did not reject the hypothesis of representation of sample concentration data by the log-normal probability distribution ( $\mathrm{p}$-value $>0.05$ ), which allowed the use of the methodology developed by Niku et al. (1979). Several studies have reported that the log-normal probability distribution describes the behavior of BOD and TSS data in WWTP 
effluents (Dean and Forsythe, 1976; Niku et al., 1979; 1981; Oliveira and Von Sperling, 2008; Owusu-Ansah et al., 2015). Although Log-normal is presented as a reference for WWTP effluent statistics, Kumar Gupta and Shrivastava (2006) and Vera et al. (2011) argue that other distributions also provide a good description of the data. In these cases, the proposed methodology would not be applicable and the effluent value distribution should be treated independently.

For the $95 \%$ reliability level, the COR values decrease with the CV increase. Non parametric tests (Kruskal-Wallis) concluded that, for the same parameter, the COR values do not differ statistically between the ponds $(\mathrm{p}<0.05)$. Contrary to what Alderson et al. (2015) states, a low COR value does not necessarily imply the malfunctioning of the treatment plant, but simply indicates less stable operational conditions due to the greater variability of data expressed by the $\mathrm{CV}$. For thermotolerant coliforms, the fact that the microbiological indicator count ranges according to many orders of magnitude explains CV values above 1.0.

Figure 5 illustrates the degree of scattering (dispersion) of COR data around the measure of centrality. It is noted that the reliability coefficient itself suffers from the fluctuation of effluent treatment technology data. The variable or combination of variables responsible for the fluctuation of effluent quality differs from plant to plant, and may be the result of design, operation or both. This is detrimental to the adoption of a single representative COR of the treatment technology because it can lead to unrealistic predictions by not considering the coefficient range of variation.

\subsection{Design concentration and coefficient of reliability application}

Since WSP systems do not have adjustable controls once in operation, the potential for use of the COR lies in the design stage:

Example 1: Consider the discharge standard of $120 \mathrm{mg} \mathrm{L}^{-1}$ for COD to be met in the final effluent of the secondary maturation pond. For a COR value between 0.73 and 0.55 (Figure 5.c), the pond design should consider a final average COD concentration between 88 and 66 $\mathrm{mg} \mathrm{L}^{-1}$ to comply with the norm limit during $95 \%$ of the time. Notice that as the parameter's COR decreases, the average design concentration decreases accordingly.

Also, by working with the results of other similar WWTP, the use of the COR allows the introduction of a probabilistic safety factor in deterministic models based on the assumption of steady state:

Example 2: Suppose a parameter that can be modeled according to first order kinetics, such as organic matter (Sun and Saeed, 2009; Silva et al., 2010), ammoniacal nitrogen (Camargo Valero and Mara, 2010; Bastos et al., 2018) and coliforms (Macedo et al., 2011). The mass balance in the first order models consists of an overall reaction rate equation coupled with boundary conditions of the reactor flow patterns, resulting in a conceptually simple model (Ho et al., 2017). These flow patterns are often considered as the idealized regimes of complete-mix or plug-flow, the theoretical limits within which all reactors fit. Once the final concentration $(M x)$ required to meet a certain quality standard $(X s)$ is known, the required hydraulic retention time $(H R T)$ can be calculated from the affluent concentration (Mo) and the model kinetic coefficient $(k)$ (Figure 6).

The applicability of COR depends on the capacity of the technology to achieve the desired reliability level related to the discharge standard. The distance from the $95 \%$ reliability scenario is shown in Figure 7 by the ratio of the observed mean concentration $(\bar{X})$ and the mean design concentration $(\mathrm{Mx})$ for each pond in the series. For a ratio equal to 1, the observed effluent concentration for the parameter coincides with the required design value. Except for the CODf in the final effluent and ammonia with less restrictive standards, the observed ratios were much higher than 1. This suggests that the $95 \%$ reliability scenario is not feasible and that less restrictive discharge limits should be applied to the parameters considered in this study. 


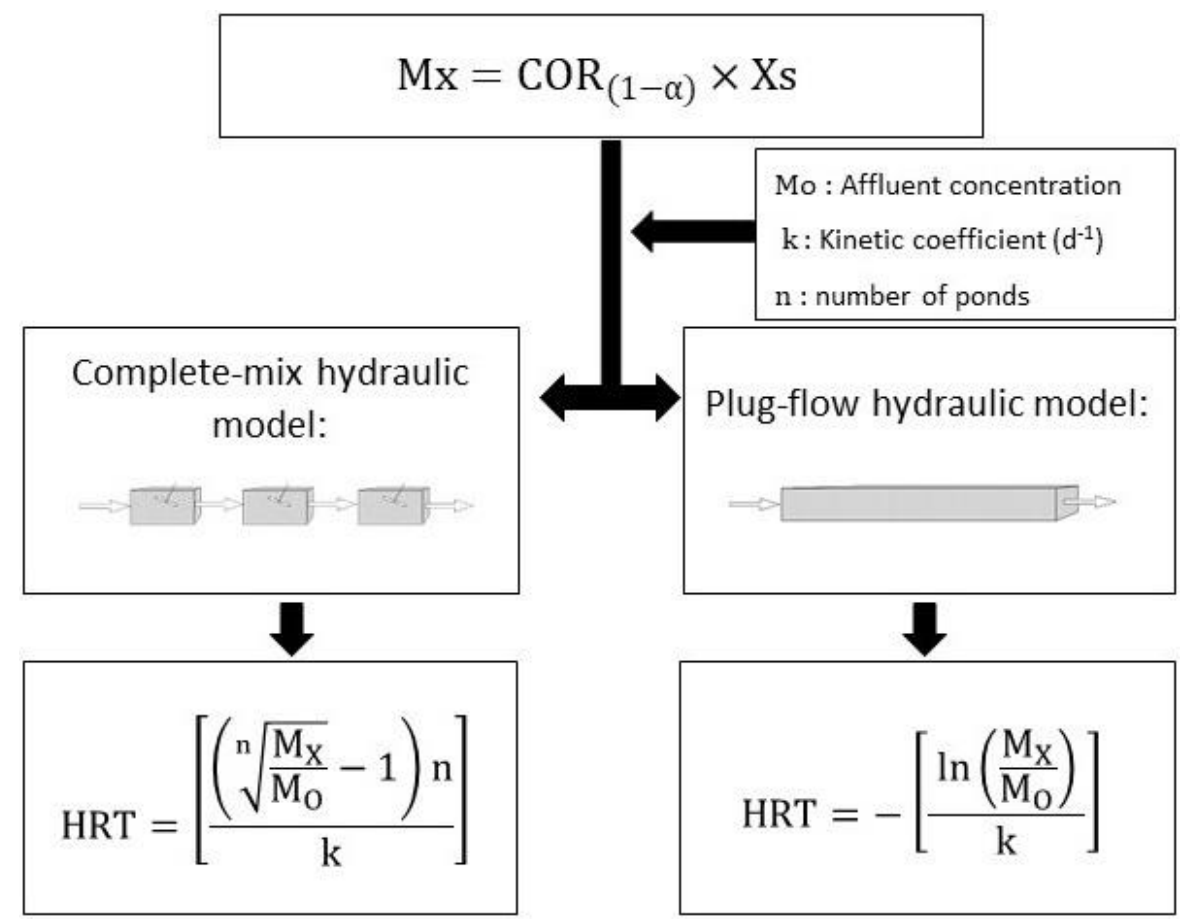

Figure 6. A stepwise approach for the design of Waste Stabilization Ponds from the coefficient of reliability (COR) and design concentration $(M x)$, calculated for a $(1-\alpha) \%$ reliability level.
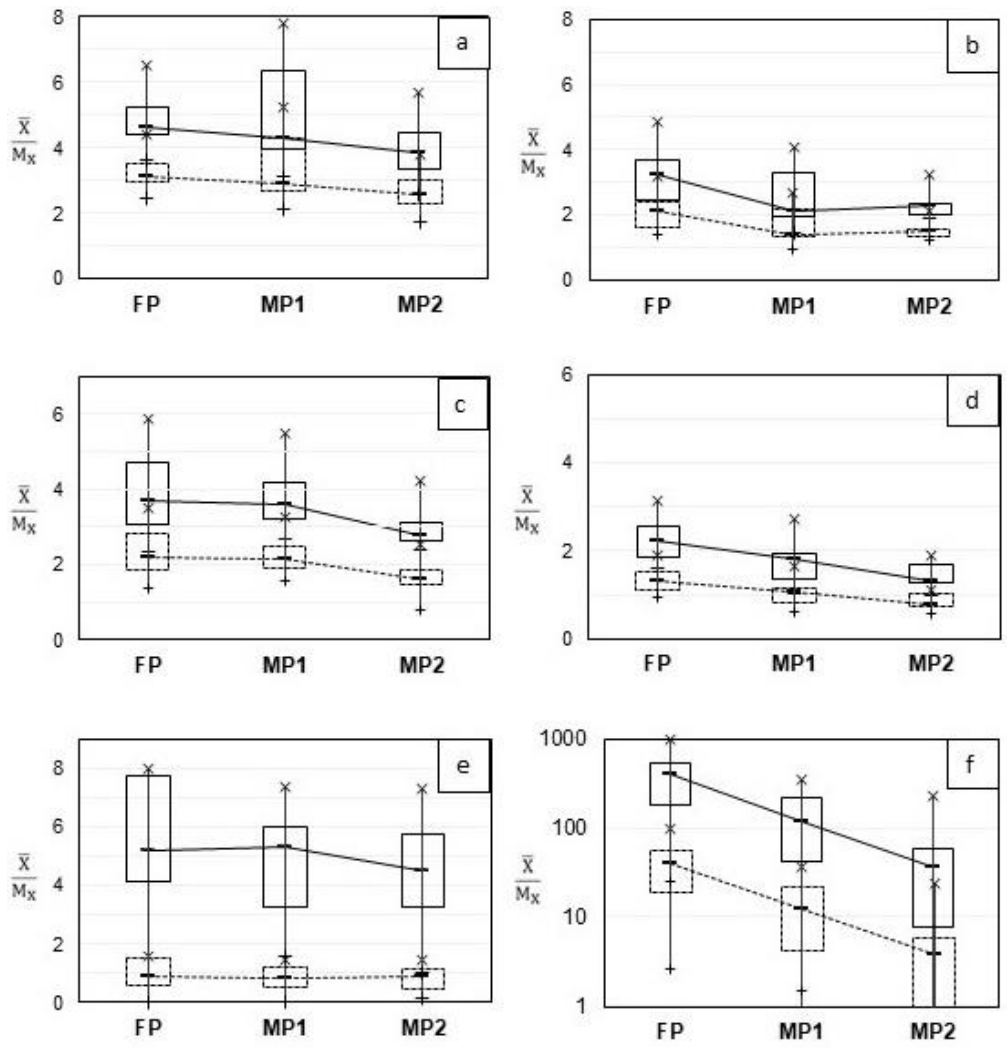

Figure 7. Ratio of observed $(\bar{X})$ and project $(\mathrm{Mx})$ concentrations for BOD (a), BODf (b), COD (c), CODf (d), TAM (e), and TTC (f) with 95\% reliability level, considering restrictive (continuous line) and less restrictive (dashed line) limits. 


\section{CONCLUSIONS}

The 10 Waste Stabilization Pond (WSP) systems in northeastern Brazil showed great variability in complying with the quality standards established for the final effluent. The particulate material attributed to algae interfered negatively in the percentages of compliance with the stipulated limits for BOD and COD. Furthermore, the systems showed difficulty and, in several cases, total inability to achieve restrictive discharge standards for thermotolerant coliforms and ammonia.

The potential for using the coefficients of reliability (COR) in the design of similar WSP systems was discussed, considering the accommodation of the expected variability in the effluent. The K-S test, applied as an "eliminatory" criterion, showed that the lognormal distribution function is able to describe the concentration data set. Compared to other quality parameters, thermotolerant coliforms presented the highest coefficients of variation and, therefore, the lowest COR values. The dispersion observed in the COR results is detrimental to the use of a single value for a given parameter that is representative of the technology. Except for COD of filtered samples and ammonia, the observed mean concentrations proved to be much higher than those required to ensure a $95 \%$ reliability scenario. Therefore, when applying the methodology discussed here, the variability of the COR and the ability of the technology to achieve the established level of reliability must always be considered.

\section{ACKNOWLEDGMENT}

The authors acknowledge the financial support given by CAPES and CNPq.

\section{REFERENCES}

ALDERSON, M. P.; SANTOS, A. B. dos; MOTA FILHO, C. R. Reliability analysis of lowcost, full-scale domestic wastewater treatment plants for reuse in aquaculture and $\begin{array}{llllll}\text { agriculture. Ecological Engineering, v. 82, p. 6-14, } 2015 . & \end{array}$ https://dx.doi.org/10.1016/j.ecoleng.2015.04.081

ANDRAKA, D. Reliability Evaluation of Wastewater Treatment Plant Impact on the Receiving Waters. Journal of Ecological Engineering, v. 20, n. 8, p. 226-231, 2019. https://dx.doi.org/10.12911/22998993/111713

APHA; AWWA; WEF. Standard Methods for the examination of water and wastewater. $22^{\text {nd }}$ ed. Washington, 2012. $1496 \mathrm{p}$.

BASTOS, R. K. X.; RIOS, E. N.; SÁNCHEZ, I. A. Further contributions to the understanding of nitrogen removal in waste stabilization ponds. Water Science and Technology, v. 77, n. 11, p. 2635-2641, 2018. https://dx.doi.org/10.2166/wst.2018.218

BENEDETTI, L.; DE KEYSER, W.; NOPENS, I.; VANROLLEGHEM, P. A. Probabilistic modelling and evaluation of wastewater treatment plant upgrades in a water quality-based evaluation context. Journal of Hydroinformatics, v. 12, n. 4, p. 380-395, 2010. https://dx.doi.org/10.2166/hydro.2010.011

CAMARGO VALERO, M. A.; MARA, D. D. Ammonia volatilization in waste stabilization ponds: a cascade of misinterpretations? Water Science \& Technology, v. 61, n. 3, p. 555-561, 2010. https://dx.doi.org/10.2166/wst.2010.856 
CONAMA (Brasil). Resolução ${ }^{\circ} 430$ de 13 de maio 2011. Dispõe sobre as condições e padrões de lançamento de efluentes, complementa e altera a Resolução no 357, de 17 de março de 2005, do Conselho Nacional do Meio Ambiente-CONAMA. Diário Oficial [da] União: seção 1, Brasília, DF, n. 92, p. 89, 16 maio 2011.

DEAN, R. B.; FORSYTHE, S. L. Estimating the reliability of advanced waste treatment - Part 1. Water \& Sewage Works, v. 123, n. 6, p. 87-89, 1976.

HO, L. T.; VAN ECHELPOEL, W.; GOETHALS, P. L. M. Design of waste stabilization pond systems: A review. Water Research. v. 123, p. 236-248, 2017. https://dx.doi.org/10.1016/j.watres.2017.06.071

KUMAR GUPTA, A.; SHRIVASTAVA, R. K. Uncertainty Analysis of Conventional Water Treatment Plant Design for Suspended Solids Removal. Journal of Environmental $\begin{array}{lllllll}\text { Engineering, } & \text { v. } 132, \quad \text { n. } 11, \quad \text { p. } 1413-1421,\end{array}$ https://dx.doi.org/10.1061/(ASCE)0733-9372(2006)132:11(1413)

LIMPERT, E.; STAHEL, W.; ABBT, M. Log-normal distributions across the sciences: keys and clues. Bioscience, v. 51, n. 5, p. 341-352, 2001.

MACEDO, S. L.; ARAÚJO, A. L. C.; PEARSON, H. W. Thermo-tolerant coliform bacteria decay rates in a full-scale waste stabilization pond system in Northeast Brazil. Water Science and Technology, v. 63, n. 6, p. 1321-1326, 2011. https://dx.doi.org/10.2166/wst.2011.110

MARA, D. Domestic Wastewater Treatment in Developing Countries. London: Earthscan, 2003.

MORAIS N. W. S.; DOS SANTOS A. B. Análise dos padrões de lançamento de efluentes em corpos hídricos e de reúso de águas residuárias de diversos estados do Brasil. Revista DAE, v. 215, n. 67, p. 40-55, 2019.

NIKU, S.; SCHROEDER, E. D.; SAMANIEGO, F. J. Performance of activated sludge process and reliability-based design. Journal Water Pollution Control Association, v. 51, n. 12, p. 2841-2857, 1979.

NIKU, S.; SCHROEDER, E. D. Factors affecting effluent variability from activated sludge processes. Journal Water Pollution Control Association, v. 53, n. 5, p. 546-559, 1981.

OWUSU-ANSAH, E. D. J.; SAMPSON, A.; AMPONSAH, S. K.; ABAIDOO, R. C.; HALD, T. Performance, Compliance and Reliability of Waste Stabilization Pond: Effluent Discharge Quality and Environmental Protection Agency Standards in Ghana. Research Journal of Applied Sciences, Engineering and Technology, v. 11, p. 1293-1302, 2015. https://dx.doi.org/10.19026/rjaset.10.1825

OLIVEIRA, S. C.; VON SPERLING, M. Reliability analysis of wastewater treatment plants. $\begin{array}{llllllll}\text { Water Research. } & \text { v. } 42, \quad \text { n. } 4, & \text { p. } & 1182-1194,\end{array}$ https://dx.doi.org/10.1016/j.watres.2007.09.001

SILVA, F. J. A.; SOUZA R. O. de; CASTRO, F. J. F. de; ARAÚJO, A. L. C. Prospectus of waste stabilization ponds in Ceará, Northeast Brazil. Water Science and Technology, v. 63, n. 6, p. 1265-1270, 2011. https://dx.doi.org/10.2166/wst.2011.106 
SILVA, F. J. A., SOUZA, R. O; ARAÚJO, A. L. C. Revisiting the Influence of Loading on Organic Material Removal in Primary Facultative Ponds. Brazilian Journal of Chemical Engineering, v. 27, n. 1, p. 63-69, 2010. https://dx.doi.org/10.1590/S010466322010000100005

SUN, G.; SAEED, T. Kinetic modelling of organic matter removal in 80 horizontal flow reed beds for domestic sewage treatment. Process biochemistry, v. 44, n. 7, p. 717-722, 2009. https://dx.doi.org/10.1016/j.procbio.2009.03.003

TCHOBANOGLOUS, G.; BURTON, F. L.; STENSEL, H. D. Wastewater engineering. Treatment and reuse. 4th ed. New York: McGraw-Hill Education, 2003.

VERA, I.; GARCÍA, J.; SÁEZ, K.; MORAGAS, L.; VIDAL, G. Performance evaluation of eight years' experience of constructed wetland systems in Catalonia as alternative treatment for small communities. Ecological Engineering, v. 37, n. 2, p. 364-371, 2011. https://dx.doi.org/10.1016/j.ecoleng.2010.11.031

VON SPERLING, M.; VERBYLA, M. A.; OLIVEIRA, S. M. A. C. Assessment of Treatment Plant Performance and Water Quality Data: A Guide for Students, Researchers and Practitioners. IWA Publishing, 2020. https://dx.doi.org/10.2166/9781780409320

WEIRICH, S. R.; SILVERSTEIN, J.; RAJAGOPALAN, B. Effect of average flow and capacity utilization on effluent water quality from US municipal wastewater treatment facilities.

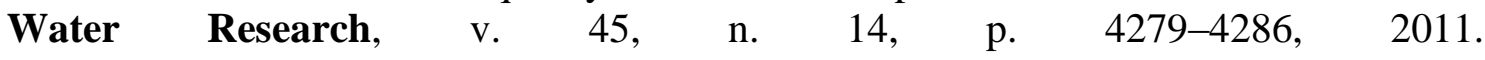
https://dx.doi.org/10.1016/j.watres.2011.06.002 